EIJEST

\title{
NUMERICAL SIMULATION OF FLOOD INUNDATION OF DELTA LANDS IN CASE OF ASWAN HIGH DAM FAILURE*
}

\author{
Esam El-deen y. Helal ${ }^{1}$, Mohamed M. Sobeih, Ahmed M. El-Belasy ${ }^{2}$, Adel M. El-gendy ${ }^{3+}$ \\ ${ }^{1}$ Civil Eng. Dept, Faculty of Eng., Menoufia University, Egypt. \\ ${ }^{2}$ Hydraulics Research Institute, National Water Research Centre, Egypt. \\ ${ }^{3}$ General Director of Water Distribution - Ministry of Water Resources \& Irrigation, Egypt.
}

\begin{abstract}
This study aims to assess the impact of Aswan high dam failure on the inhabited areas downstream of the Delta barrages to the Mediterranean sea or any urban area which may be in the path of the flood surge waves. The study was based on a large amount of available hydraulic data that were analyzed and used as input to the numerical model SOBEK-1D2D. The problem was studied by simulations performed along the Nile branches as (1D) and Delta lands as (2D). Results such as the inundated area of delta lands, flood depth, flow velocity and travel time of flood wave propagations along Damietta and Rosetta branches were obtained to define the time of response for emergency measures. So the size of expected damage of national main structures, within the extension of the study area (Railways, roads, etc) was identified. GIS maps were prepared to evaluate the effects of the dam failure on the inundated area. Suggestions for the emergency procedures are given. The results which could be part of a flood management plan, propose mitigation plans against inundation and warning system. Finally, the important benefit of the study is that future construction projects and must be outside the boundary of expected inundation area.
\end{abstract}

KEY WORDS: Catastrophic Flooding, Risk Analysis, Inudation Area, Aswan High Dam Failure.

\section{SIMULATION NUMÉRIQUE DE CRUES INONDATION DES TERRES EN RAISON DE DELTA HAUT BARRAGE D'ASSOUAN PANNE}

\section{RÉSUMÉ}

Cette étude vise à évaluer l'impact d'Assouan échec élevé des barrages sur les zones habitées en aval des barrages Delta vers la mer Méditerranée ou de toute zone urbaine qui peuvent être dans le chemin des ondes de surtension d'inondation. L'étude a été basée sur une grande quantité de données disponibles hydrauliques qui ont été analysés et utilisés comme entrée pour le modèle numérique SOBEK - 1D2D. Le problème a été étudié par des simulations effectuées le long des branches du Nil comme (1D) et des terres du Delta comme (2D). Des résultats tels que la zone inondée des terres du delta, la profondeur d'inondation , la vitesse d'écoulement et le temps de Voyage de propagations d'ondes d'inondation le long de Damiette et de Rosette branches ont été obtenus pour définir le temps de réponse pour les mesures d'urgence. Ainsi, la taille des dommages prévus des structures nationales principales, dans le prolongement de la zone d'étude (chemins de fer, routes, etc.) a été identifié. Cartes SIG ont été préparés pour évaluer les effets de la rupture d'un barrage sur la zone inondée. Suggestions pour les procédures d'urgence sont données. Les résultats qui pourraient faire partie d'un plan de gestion des inondations, proposer des plans d'atténuation des inondations et d'alerte. Enfin, l'avantage important de l'étude est que les futurs projets de construction et doit être en dehors de la zone d'inondation ofexpected limite.

MOTS CLÉS: Inondations Catastrophiques, Analyse Des Risques, Inudation Région, Haut Barrage d'Assouan Echec.

* Received: 19/8/2013, accepted: 2/10/2013, Ref. No. 161, (Original paper)

+ Contact author (01015159716) 


\section{NUMERICAL SIMULATION OF FLOOD INUNDATION OF DELTA LANDS IN CASE OF ASWAN HIGH DAM FAILURE}

Helal, Sobeih, El-Belasy, El-gendy

\section{INTRODUCTION}

Within Egypt the River Nile is controlled by two dams at Aswan and a series of seven barrages which are among the most important hydraulic structures in the Egyptian water controls system. They regulate the Nile flow discharge and water levels. In addition to the Aswan High Dam, some of these barrages are producing hydropower. The Nile in Egypt consists of two parts, the Nile valley and the Nile delta. The delta barrages Barrage which were constructed in 1939 at Km 953.5 from Aswan Old Dam.

Recent economic activities especially agriculture and industry activities and populations around delta lands have increased the need for risk management and assessment of damage due to dam failure which can lead to enormous loss of life and property. Flood inundation due to dam failure happens occasionally in the world. Such an event may cause serious loss of life, property, environmental damage, and economic repercussions. This study was put on track with the objective of analysis the hydraulic hazards of inundation of delta lands due to the failure of Aswan High Dam. This study aims to assess the impact of such a catastrophic event on the inhabited areas downstream of the delta barrage to the Mediterranean Sea, or any urban area which might be in the path of the flood surge waves.

During the prediction, the following are achieved:

- The inundated area of delta lands in order to determine possible damages;

- The impact of dam failure on other structures along the Nile River is defined;

- Depth and velocity of flood water (allowing estimation of damage potential);

- The travel time of the flood waves propagations along the Damietta and Rosetta branches have to be calculated in order to define the time of response for emergency measures to be operated;
- The expected damage of national main structures, (Railways, roads, etc) within the extension of the study area was identified;

- Peak water level - extent of inundation;

- Time of peak water level;

- GIS maps were prepared to evaluate the effects of dam failure on extending of delineating area which would be inundated.

\section{LITERATURE REVIEW}

Flood due to failure of dams induces widespread damages to life and property owing to its high magnitude and unpredictable sudden occurrence. Such flood is required to be simulated to determine the inundated area, flood depth and travel time of the flood waves so that adequate safety measurs can be provided. Therefore, it is a useful tool for establishing flood control and developing evacuation plans and warning systems for the areas having potential flood risk.

Mathematical models are considered powerful tools to assess the impact of flood due to dam failure events. These numerical models were developed and improved from 1D models to 2D models, most of these models formulation are based on the Saint-Venant equations applied to gradually varied unsteady flow, as follows:

- Continuity equation

$\frac{\partial A_{t}}{\partial t}+\frac{\partial Q}{\partial x}=q_{L}$

- Momentum equation

$\frac{\partial Q}{\partial t}+\frac{\partial}{\partial x}\left(\alpha_{B} \frac{Q^{2}}{A_{f}}\right)+g A_{f} \frac{\partial h}{\partial x}+\frac{g Q|Q|}{C^{2} R A_{f}}=0$.... (2)

where: $A_{f}=$ conveying cross-section, $A_{t}=$ total cross sectional area, $C=$ Chézy coefficient, $g$ = gravitational acceleration, $h=$ water level relative to reference level, $q_{L}=$ lateral inflow per unit length, $Q=$ discharge, $R=$ hydraulic radius (roughly equal to the water 


\section{NUMERICAL SIMULATION OF FLOOD INUNDATION OF DELTA LANDS IN CASE OF ASWAN HIGH DAM FAILURE}

Helal, Sobeih, El-Belasy, El-gendy

depth), $t=$ time, $W_{f}=$ width of conveying cross-section at water surface, $x=$ distance along the channel and $\alpha_{B}=$ Boussinesq coefficient.

These hydraulic models of unsteady flow were employed with combining with other computer applications, i.e. Geographic Information System, (GIS) network, providing new hydraulic simulations and producing more accurate friendly predicted results.

Dhondia et al. [2] illustrated that the SOBEK-Rural was applied to simulate the flood and assess the damage in the Sistan-Baluchistan River Basin in Iran. The main objective of the study was to assess the effectiveness of the flood control measures constructed in this region based on the available data from flood of year 1992. Thus, the Digital Elevation Model (DEM) of the Sistan-Baluchistan River basin area was built using SOBEK-1D2D. The combined 1D-2D modeling, gave the inundation map, and highlighted the possibilities for studying flood control measures, flood forecasting, and development of flood evacuation plans.

The SOBEK-1D2D integration can be illustrated by examining alternative flood scenarios for the Geldersche Valley in the centre of the Netherlands [7]. The model study had the objective of assessing flood damage and establishing evacuation plans for a number of flood scenarios. Model results showed that, the development of a breach during the passage of the 1:1250 year frequency flood peak on the Rhine. EL-Belsay A. [3] studied the inundation for the Nile Delta due to expected high discharges from delta barrages using SOBEK1D2D in order to determine the flooded areas for several high discharge releases by producing hazard maps for the Nile Delta. Hassan [6] illustrated the analysis of hydraulic hazards of inundation of Delta lands due to Delta barrages failure by simulating the delta barrages failures by SOBEK 1D2D model and estimation the flooding area in the Nile Delta Land under different flow conditions. 


\section{NUMERICAL SIMULATION OF FLOOD INUNDATION OF DELTA LANDS IN CASE OF ASWAN HIGH DAM FAILURE}

Helal, Sobeih, El-Belasy, El-gendy

spatially varying surface roughness and wind friction [8].

\subsection{Model Set Up}

Generally, the steps taken to simulate surface-water flow using SOBEK-1D2D is as follows: Data assessment, Network design, Model calibration, Model validation and Model application. These five steps are followed during the application of numerical models.

\subsection{Model Schematization}

The model schematization will be concerned with 3 reaches (The River Nile US Delta Barrage and its branches DS Delta Barrage) to simulate the $1 \mathrm{D}$ modeling of the river flow and concerned with 2D overland flow (DEM of Delta Lands).

The River Nile US Delta Barrage and its branches DS Delta Barrage were modeled as follows:

- The modeled River Nile US Delta Barrage has length $11.0 \mathrm{Km}$ according to the study reaches.

- The modeled Damietta Branch DS Delta Barrage has length $245.807 \mathrm{~km}$. It is divided into 3 reaches by Zefta Barrages and Damietta Dam. $1^{\text {st }}$ reach starts from DS Delta Barrage to US Zefta barrage with a length of 94.285 $\mathrm{km} .2^{\text {nd }}$ reach starts from DS Zefta barrage to US Damietta Dam with a length of 134.109 km. $3^{\text {rd }}$ starts from DS Damietta Dam to the Mediterranean Sea with a length of 17.413 $\mathrm{km}$.

- The modeled Rosetta Branch DS Delta Barrage has length $229.995 \mathrm{~km}$. It is divided into 2 reaches by Idfina Barrages. $1^{\text {st }}$ reach starts from DS Delta Barrage to US Idfina barrage with a length of $196.198 \mathrm{~km} .2^{\text {rd }}$ starts from DS Idfina Barrages to the Mediterranean Sea with a length of $33.797 \mathrm{~km}$.

The Nile Delta which was simulated in 2D model is $54662 \mathrm{~km}^{2}$

Figure (1) shows the schematization of the Nile US Delta Barrages, the Nile Delta Branches (Damietta, Rosetta, with their nodes, reaches and its main structures) and DEM of the Nile Delta Lands.

\subsubsection{Boundary conditions}

SOBEK is based on the unsteady flow regime, so it needs to be provided boundary conditions at the upstream flow and outflow boundaries, and lateral discharges. The following conditions are considered:

- US conditions: were applied at the upstream of Delta Barrage by $11 \mathrm{~km}$ according to the study reach. The water levels were entered to the model in $\mathrm{m}$ with its time in hr, figure (2).

- DS conditions: were assumed to be the water level downstream of Damietta dam and Idfina Barrage that is the water level in Mediterranean Sea.

- Lateral in/outflow were specified for both point discharges $\left(\mathrm{m}^{3} / \mathrm{s}\right)$ for the main canals and all pumps that directly withdraw off the river, all minor abstraction canals and all drains returning water to the river within the reach under consideration.

Figure (1): Digital elevation model (DE the Nile Delta

\subsubsection{Numerical grid and time step}

Numerical grid was considered as the following:

- In 1D: The dimension of the grid cells in all reaches of the Nile River was $200 \mathrm{~m}$. The calculations were executed to the segments, structures and the intermediate nodes to produce the water levels, depths, velocities, discharges and some hydraulic characteristics. 


\section{NUMERICAL SIMULATION OF FLOOD INUNDATION OF DELTA LANDS IN CASE OF ASWAN HIGH DAM FAILURE}

Helal, Sobeih, El-Belasy, El-gendy

- In 2D: The cell in the 2D has to be connected with only one calculation or one connection node for 1D model. A spatial step of 250 meter provides a good balance between numerical accuracy and computational effort.

Time step and Simulation period were considered as follows:

- Time step: it was chosen one hour.

- Simulation period: it was six months period after failure.

\subsection{Model Calibration and Validation}

Calibration and validation of the model of Damietta Branch were carried out based on real measurements of inflows, discharges, and water levels. The measurements were taken during year 2010. Differences between measured and computed water levels were ranged from $0.5 \%$ to $5 \%$.

\section{BASIC ASSUMPTIONS}

The following basic assumptions are considered for simulation:

- The US boundary conditions of SOBEK are set as the water levels US Delta Barrages which are calculated for scenario (1) after Fahmy [5], figure (2). The DS boundary conditions are set as the Mediterranean Sea.

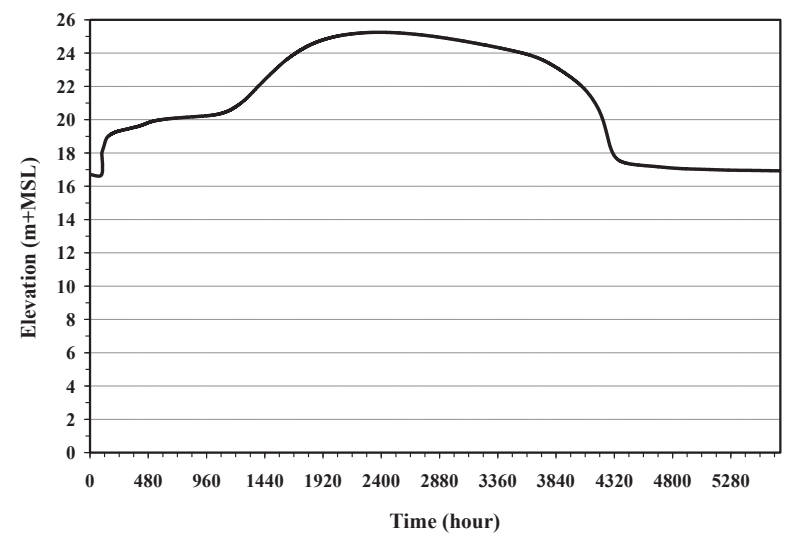

Figure (2): Upstream Delta Barrage water levels, (after Fahmy [5])

- The simulation period is 6 months and the time step is 1 hour.

- Bank failure does not occur due to excessive

discharges.

- The debris, present in the barrages fore-bays that could obstruct the vents during the passage of the flood wave, is absent.

- All gates of the main barrages, downstream of the AHD, are opened when the flood wave reaches them. These barrages are sabotaged when the flood discharge reaches $7000 \mathrm{~m}^{3} / \mathrm{s}$.

- The bridges, along the Nile, are sabotaged when the water level reaches their deck.

- Erosion does not take place during the simulations.

- The lateral off-takes, all side canals and Rayahs upstream of the barrages are worked with their maximum capacity during the flood.

\section{FLOOD SIMULATION}

Flood simulate is used to determine the inundated area, flood depth and travel time of the flood wave so that adequate safety measures can be provided.

The hypothetical failure of the AHD due to this risk causes the highest damages along the Nile Delta Branches, These results are presented in Tables (1) and (2) and can be discussed as follows:

\section{Damietta Branch}

The flood wave reaches DS Delta Barrage after 95 hr. The maximum water level DS Delta Barrages $22.16 \mathrm{~m}$ was attended after $2389 \mathrm{hr}$. The water levels increases by $7.77 \mathrm{~m}$ in the fore-bay. The maximum flow $5,515.64 \mathrm{~m}^{3} / \mathrm{s}$ is reached. A maximum velocity of $1.98 \mathrm{~m} / \mathrm{s}$ was occurs.

Banha city is the first city touched by the flood wave after $97 \mathrm{hr}$. The maximum water level 15.40 $\mathrm{m}$ is attended after $2444 \mathrm{hr}$. The water levels increases by $4.64 \mathrm{~m}$ in the fore-bay. The maximum flow $3,117.27 \mathrm{~m}^{3} / \mathrm{s}$ is reached. A maximum velocity of $1.44 \mathrm{~m} / \mathrm{s}$ happens.

Kafr Shukr city is the first city touched by the flood wave after $98 \mathrm{hr}$. The maximum water level $14.09 \mathrm{~m}$ is attended after $2455 \mathrm{hr}$. The water levels increased by $3.94 \mathrm{~m}$ in the fore-bay. The maximum flow $2,448.69 \mathrm{~m}^{3} / \mathrm{s}$ was reached. A maximum velocity of $4.25 \mathrm{~m} / \mathrm{s}$ is reached.

The remaining results of the risk analysis at the others structures and cities across 
NUMERICAL SIMULATION OF FLOOD INUNDATION OF DELTA LANDS IN CASE OF ASWAN HIGH DAM FAILURE

Helal, Sobeih, El-Belasy, El-gendy

Table (1): Hydraulics characteristics along the Damietta Branch,

\begin{tabular}{|c|c|c|c|c|c|c|c|}
\hline $\begin{array}{c}\text { Distance from } \\
\text { Delta Barrage } \\
(\mathrm{Km}) \\
\end{array}$ & Description & $\begin{array}{c}\text { Initial } \\
\text { Water } \\
\text { Level } \\
(\mathrm{m}) \\
\end{array}$ & $\begin{array}{c}\text { Max. } \\
\text { Water } \\
\text { Level } \\
(\mathrm{m}) \\
\end{array}$ & $\begin{array}{c}\text { Time of } \\
\text { wave arrival } \\
\text { (hour) } \\
\end{array}$ & $\begin{array}{l}\text { Max. } \\
\text { Flow } \\
\left(\mathrm{m}^{3} / \mathrm{s}\right) \\
\end{array}$ & $\begin{array}{l}\text { Max. } \\
\text { Velocity } \\
(\mathrm{m} / \mathrm{s})\end{array}$ & $\begin{array}{c}\text { Time of Max. } \\
\text { Water Level } \\
\text { (hour) }\end{array}$ \\
\hline 0.00 & $\begin{array}{l}\text { DS Delta } \\
\text { Barrage }\end{array}$ & 14.39 & 22.16 & 95 & $5,515.64$ & 1.98 & 2389 \\
\hline 53.92 & Banha & 10.76 & 15.40 & 97 & $3,117.27$ & 1.44 & 2444 \\
\hline 68.69 & Kafr Shukr & 10.15 & 14.09 & 98 & $2,448.69$ & 4.28 & 2455 \\
\hline 88.77 & $\begin{array}{l}\text { Zefta - } \\
\text { Mit Ghamr }\end{array}$ & 9.29 & 11.77 & 99 & $3,414.50$ & 1.81 & 2477 \\
\hline 94.29 & $\begin{array}{l}\text { US Zefta } \\
\text { Barrage }\end{array}$ & 9.25 & 11.27 & 100 & $2,866.49$ & 1.48 & 2494 \\
\hline 94.29 & $\begin{array}{l}\text { DS Zefta } \\
\text { Barrage. }\end{array}$ & 4.15 & 11.00 & 100 & $2,866.49$ & 1.48 & 2500 \\
\hline 127.07 & Samanoud & 3.08 & 8.40 & 101 & $1,933.44$ & 1.53 & 2686 \\
\hline 146.28 & $\begin{array}{l}\text { El Mansoura - } \\
\text { Talkha }\end{array}$ & 2.24 & 7.13 & 107 & $1,594.90$ & 1.08 & 3000 \\
\hline 173.07 & Sherbin & 1.92 & 6.39 & 114 & $1,318.02$ & 0.67 & 3175 \\
\hline 184.39 & El Zarka & 1.86 & 6.26 & 116 & 1316.10 & 0.69 & 3195 \\
\hline 211.82 & $\begin{array}{l}\text { Farskor - } \\
\text { Kafr saad }\end{array}$ & 1.83 & 6.07 & 119 & 925.98 & 0.46 & 3226 \\
\hline 228.39 & $\begin{array}{l}\text { US Damietta } \\
\text { Dam }\end{array}$ & 1.82 & 6.03 & 119 & 807.21 & 5.50 & 3238 \\
\hline 228.39 & $\begin{array}{l}\text { DS Damietta } \\
\text { Dam }\end{array}$ & 0.25 & 5.89 & 119 & 807.21 & 5.50 & 3242 \\
\hline 231.44 & Damietta & 0.25 & 5.87 & 119 & 799.14 & 0.72 & 3243 \\
\hline
\end{tabular}

Damietta Branch are presented in table (1). Figures (4) and (5) present the comparison between the hydrographs (flow) at different sites (structures \& cities) across Damietta Branch. Also figures (6) and (7) present the comparison between water levels at different sites (structures \& cities) across Damietta Branch.

\section{- Generally, after the AHD failure}

The first propagating wave takes about $119 \mathrm{hr}$ to reach US Damietta Dam while under the normal flow conditions; the time of water movement from AHD to the Damietta Dam takes about 336 hr, Figure (8). 


\section{NUMERICAL SIMULATION OF FLOOD INUNDATION OF DELTA LANDS IN CASE OF ASWAN HIGH DAM FAILURE}

Helal, Sobeih, El-Belasy, El-gendy

The wave travels downstream Damietta Branch with a velocity ranges between 0.24 and 7.89 $\mathrm{m} / \mathrm{s}$, according to its natural bed slopes, and the Nile cross-section width. Figures (9) and (10) show the maximum velocity and the maximum flow along the Damietta Branch

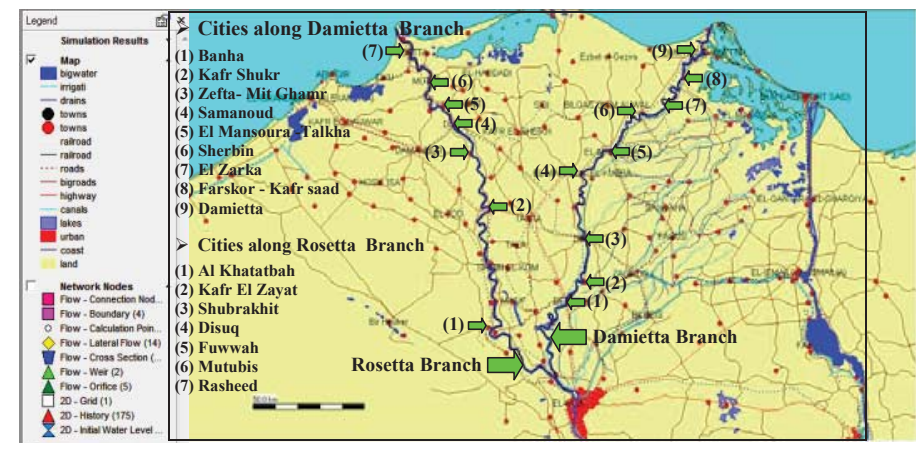

Figure (3): Cities along River Nile Branches Damietta and Rosetta

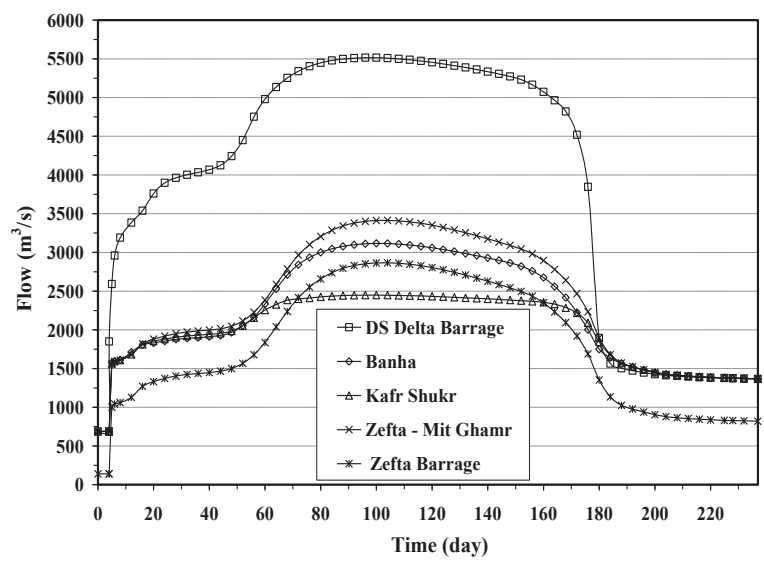

Figure (4): Hydrographs at different sites across $1^{\text {st }}$ reach of Damietta Branch

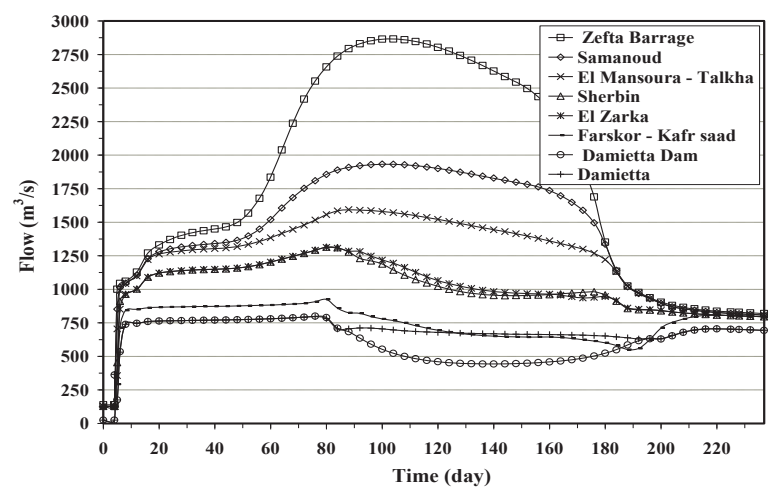

Figure (5): Hydrographs at different sites cross $2^{\text {nd }}$ and $3^{\text {rd }}$ reaches of Damietta Branch

\section{- Rosetta Branch}

The flood wave reaches DS Delta Barrage after $95 \mathrm{hr}$. The maximum water level DS Delta Barrage $22.25 \mathrm{~m}$ is attended after $2390 \mathrm{hr}$. The water levels increased by $8.81 \mathrm{~m}$ in the fore-bay. The maximum flow $6960.86 \mathrm{~m}^{3} / \mathrm{s}$ is reached. A maximum velocity of $2.58 \mathrm{~m} / \mathrm{s}$ is reached. The flood wave reaches $\mathrm{Al}$ Khatatbah city after 98 $\mathrm{hr}$. The maximum water level $16.42 \mathrm{~m}$ is attended after $2439 \mathrm{hr}$. The water levels increased by $8.80 \mathrm{~m}$ in the fore-bay. The maximum discharge $3121.32 \mathrm{~m}^{3} / \mathrm{s}$ is reached. A maximum velocity of $1.32 \mathrm{~m} / \mathrm{s}$ is reached.

Kafr El Zayat city was the first city touched by the flood wave after $108 \mathrm{hr}$. The maximum water level $9.18 \mathrm{~m}$ is attended after $2657 \mathrm{hr}$. The water levels increases by $5.75 \mathrm{~m}$. The maximum flow $4203.45 \mathrm{~m}^{3} / \mathrm{s}$ is reached. A maximum velocity of $0.66 \mathrm{~m} / \mathrm{s}$ is expected.

The results of the risk analysis at the others structures and cities across Rosetta Branch were presented in table (2). Figure (11) presented the comparison between the hydrographs (flow) at

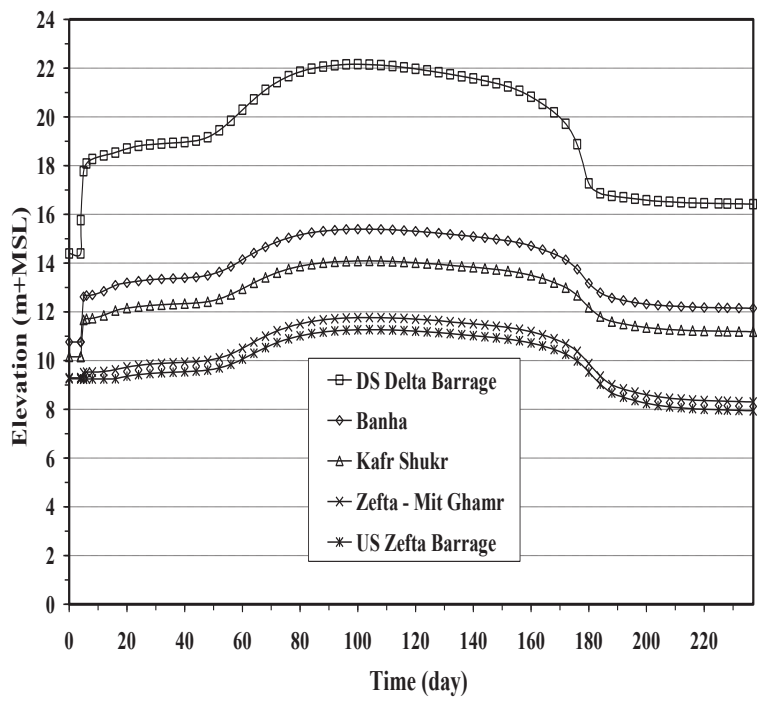

Figure (6): Water levels at different sites along $1^{\text {st }}$.reach of Damietta Branch 


\section{NUMERICAL SIMULATION OF FLOOD INUNDATION OF DELTA LANDS IN CASE OF ASWAN HIGH DAM FAILURE}

Helal, Sobeih, El-Belasy, El-gendy

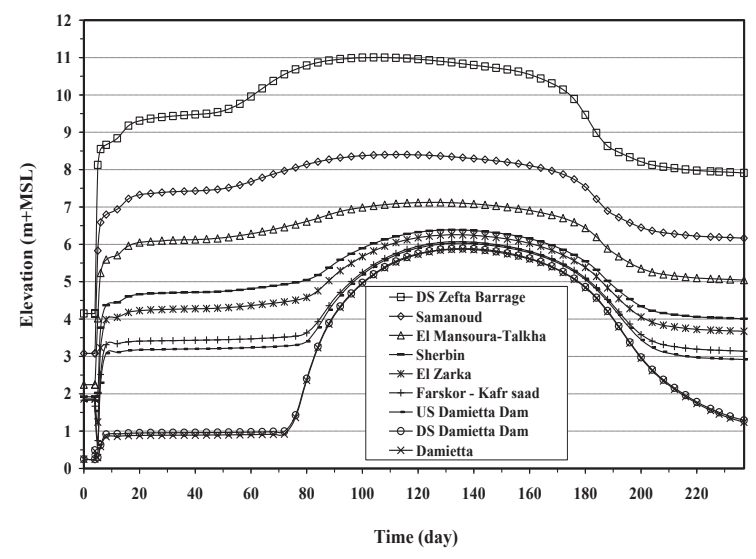

Figure (7): Water levels at different sites along $2^{\text {nd }}$ and $3^{\text {rd }}$ reaches of Damietta Branch

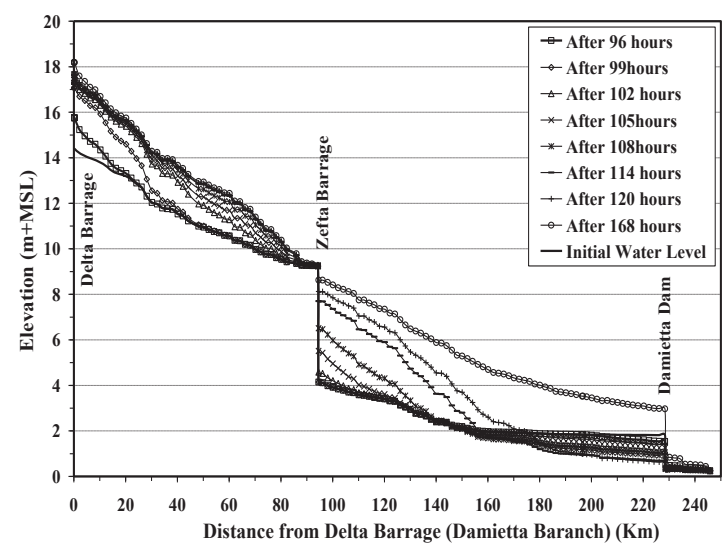

Figure (8): Longitudinal profile of flood wave propagation along

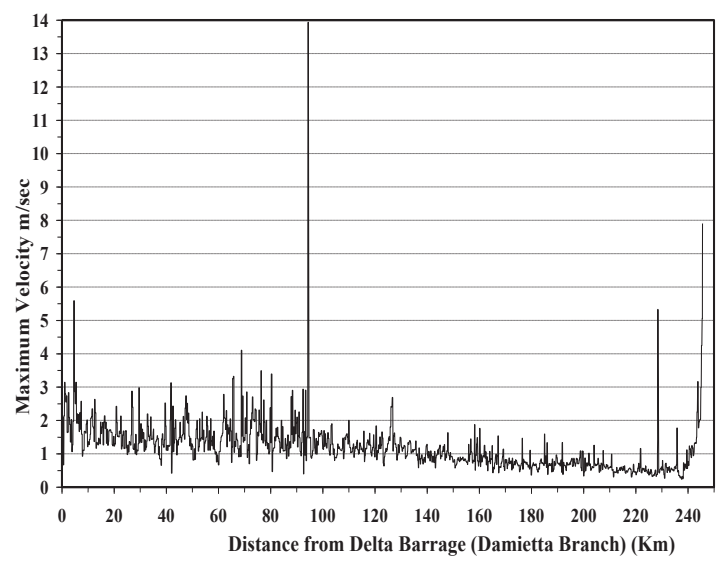

Figure (9): Max. velocity along Damietta Branch

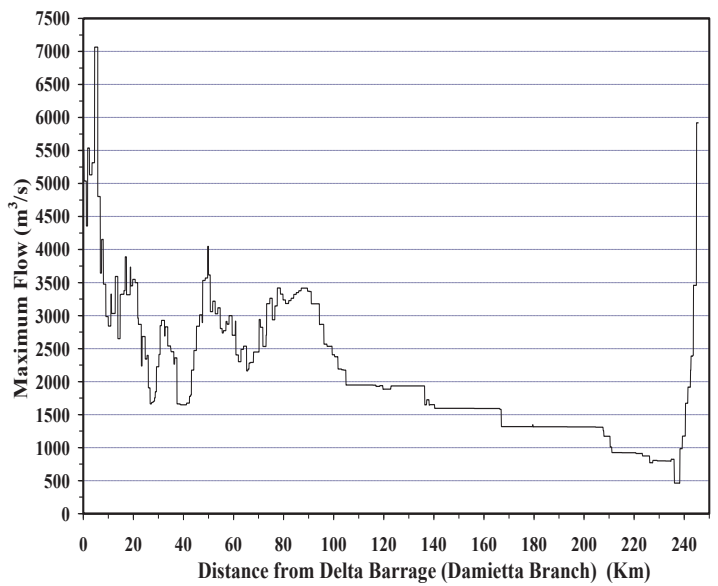

Figure (10): Max. flow along Damietta Branch

different sites (structures \& cities) across Rosetta Branch. Also figure (12) presentS the comparison between water levels at different sites (structures \& cities) across Rosetta Branch

The wave travels downstream Damietta Branch with a velocity ranges between 0.24 and $7.89 \mathrm{~m} / \mathrm{s}$, according to its natural bed slopes, and the Nile cross-section width. Figures (9) and (10) show the maximum velocity and the maximum flow along the Damietta Branch.

\section{- Generally, after the AHD failure}

The first propagating wave takes about $116 \mathrm{hr}$ to reach US Idfina Barrage while under the normal flow conditions; the time of travel from AHD to the Idfina Barrage takes about $336 \mathrm{hr}$, Figure (13).

The wave travels down Rosetta Branch with a velocity ranged between 0.30 and $6.59 \mathrm{~m} / \mathrm{s}$ according to its natural bed slopes, and the Nile cross-section width. Figure (14), (15) show the maximum velocity and maximum flow along Rosetta Branch respectively.

The wave travels down the first reach between Delta Barrage and Idfina Barrage with a velocity ranged between 0.38 and $4.63 \mathrm{~m} / \mathrm{s}$. The wave travels down the second reach between Idfina Barrage and the Mediterranean Sea with a velocity ranged between 0.30 and $6.59 \mathrm{~m} / \mathrm{s}$. 
NUMERICAL SIMULATION OF FLOOD INUNDATION OF DELTA LANDS IN CASE OF ASWAN HIGH DAM FAILURE

Helal, Sobeih, El-Belasy, El-gendy

Table (2): Hydraulics characteristics along Rosetta Branch

\begin{tabular}{|c|l|c|c|c|c|c|c||}
\hline $\begin{array}{c}\text { Distance from } \\
\text { Delta Barrage } \\
(\mathrm{Km})\end{array}$ & Description & $\begin{array}{c}\text { Initial } \\
\text { Water } \\
\text { Level }(\mathrm{m})\end{array}$ & $\begin{array}{c}\text { Max. } \\
\text { Water } \\
\text { Level }(\mathrm{m})\end{array}$ & $\begin{array}{c}\text { Time of } \\
\text { wave arrival } \\
\text { (hour) }\end{array}$ & $\begin{array}{c}\text { Max. } \\
\text { Flow } \\
\left(\mathrm{m}^{3} / \mathrm{s}\right)\end{array}$ & $\begin{array}{c}\text { Max. } \\
\text { Velocity } \\
(\mathrm{m} / \mathrm{s})\end{array}$ & $\begin{array}{c}\text { Time of Max. } \\
\text { Water Level } \\
\text { (hour) }\end{array}$ \\
\hline \hline 0.00 & $\begin{array}{l}\text { DS Delta } \\
\text { Barrage }\end{array}$ & 13.44 & 22.25 & 95 & 6960.86 & 2.58 & 2390 \\
\hline 45.03 & Al Khatatbah & 7.62 & 16.42 & 98 & 3121.32 & 1.32 & 2439 \\
\hline 115.04 & $\begin{array}{l}\text { Kafr } \\
\text { El Zayat }\end{array}$ & 3.43 & 9.18 & 108 & 4203.45 & 0.66 & 2657 \\
\hline 150.00 & Shubrakhit & 3.12 & 6.94 & 112 & 3407.00 & 0.94 & 3071 \\
\hline 166.48 & Disuq & 2.99 & 6.31 & 114 & 2936.44 & 1.06 & 3160 \\
\hline 177.97 & Fuwwah & 2.91 & 6.05 & 115 & 2696.10 & 1.30 & 3199 \\
\hline 194.70 & Mutubis & 2.88 & 5.81 & 116 & 2542.95 & 1.13 & 3221 \\
\hline 196.20 & $\begin{array}{l}\text { US Idfina } \\
\text { Barrage }\end{array}$ & 2.88 & 5.79 & 116 & 2542.86 & 1.18 & 3222 \\
\hline 196.20 & $\begin{array}{l}\text { DS Idfina } \\
\text { Barrage }\end{array}$ & 0.30 & 5.74 & 116 & 2542.86 & 1.04 & 3225 \\
\hline 215.59 & Rasheed & 0.27 & 5.39 & 117 & 3243.51 & 0.97 & 3236 \\
\hline \hline
\end{tabular}

\subsection{Bank Overtopping and Violation Sites}

If the flooding continues for 6 months until the water level profile gets down. The banks are overtopped at most of the sites along the Nile Delta Branches. Figure (16), presents the maximum water profile along Damietta Branch. Figure (17), shows the maximum water profile along Rosetta Branch.

\subsection{Inundated Areas and Maps (GIS database)}

The total gross flooded area resulted from this study is about $21833.18 \mathrm{Km}^{2}$, table (3).

Figures (18) and (19) show the GIS maps of inundated areas, and the inundated depth.

\subsection{Means of Transportations}

Emergency plan evacuates the affected areas (i.e. roads, and railways that subjected to inundation).
Roads: 107 roads with total length $2749.357 \mathrm{Km}$ will be inundated and its inundated length are $2230.657 \mathrm{~km}$.

Railways: 45 railways with total length $2204.049 \mathrm{Km}$ will be inundated and its inundated length are $1555.153 \mathrm{~km}$.

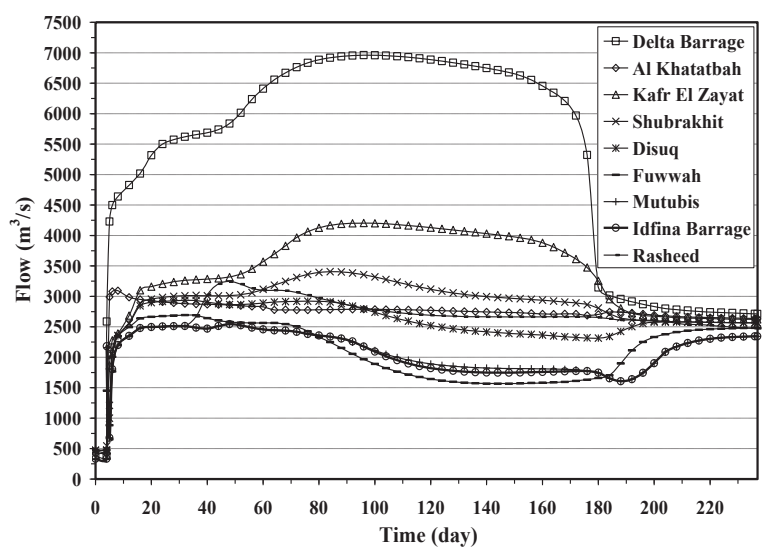

Figure (11): Hydrographs at different sites across Rosetta Branch 


\section{NUMERICAL SIMULATION OF FLOOD INUNDATION OF DELTA LANDS IN CASE OF ASWAN HIGH DAM FAILURE}

Helal, Sobeih, El-Belasy, El-gendy

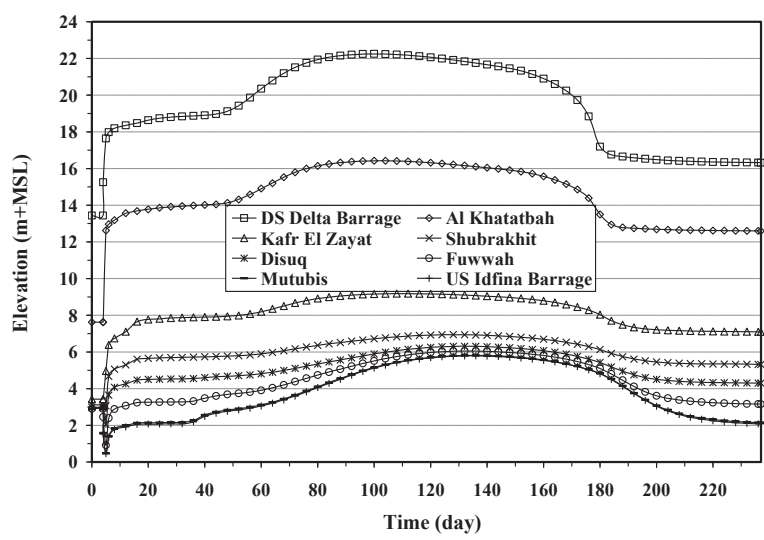

Figure (12): Water levels at different sites along Rosetta Branch

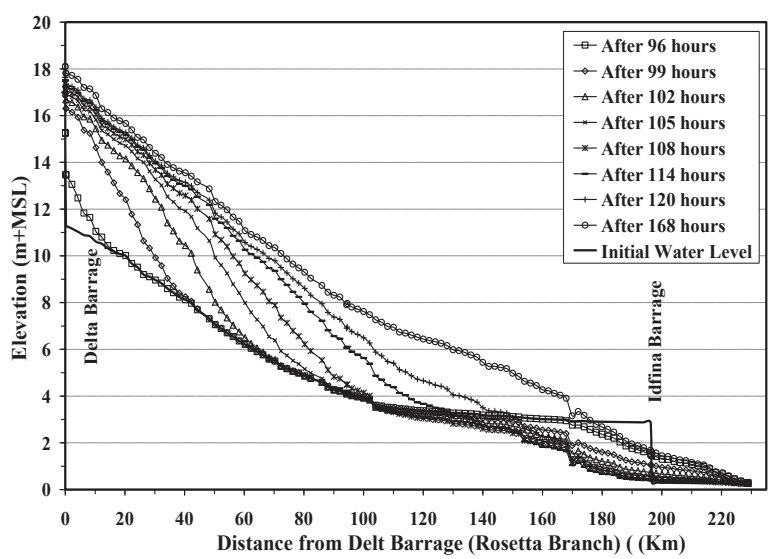

Figure (13): Longitudinal profile of flood wave propagation along Rosetta Branch

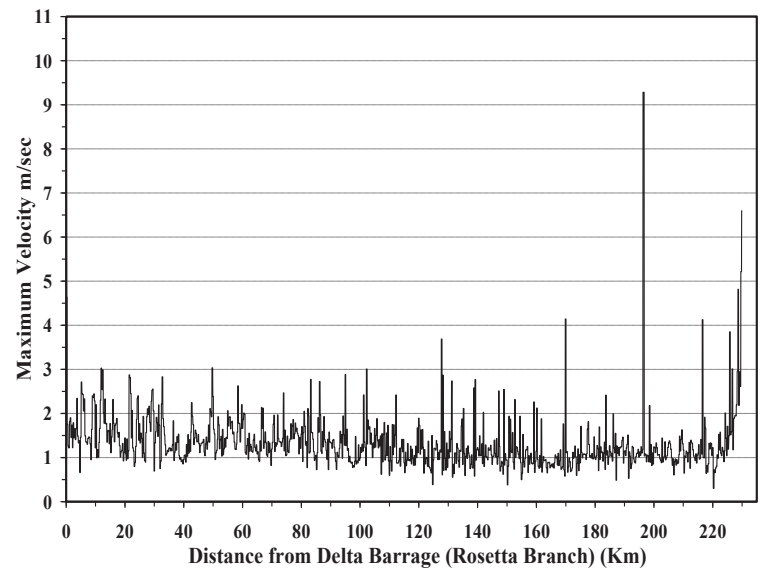

Figure (14): Max. Velocity along Rosetta Branch

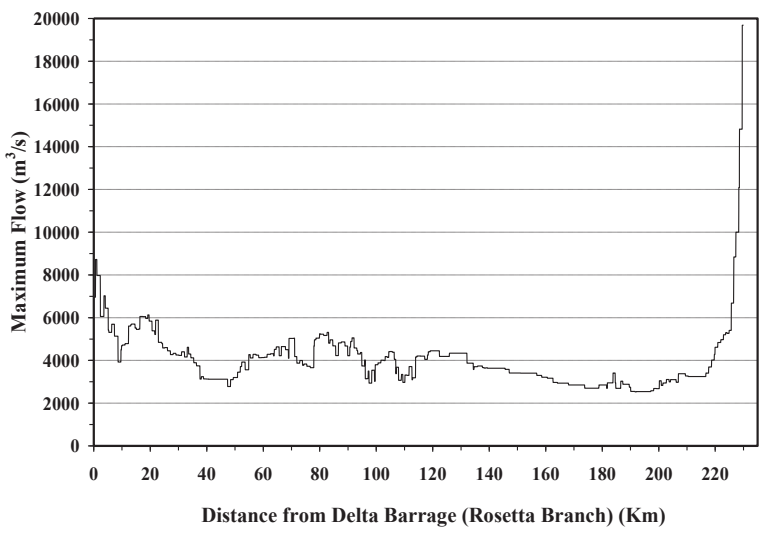

Figure (15): Max. Flow along Rosetta Branch

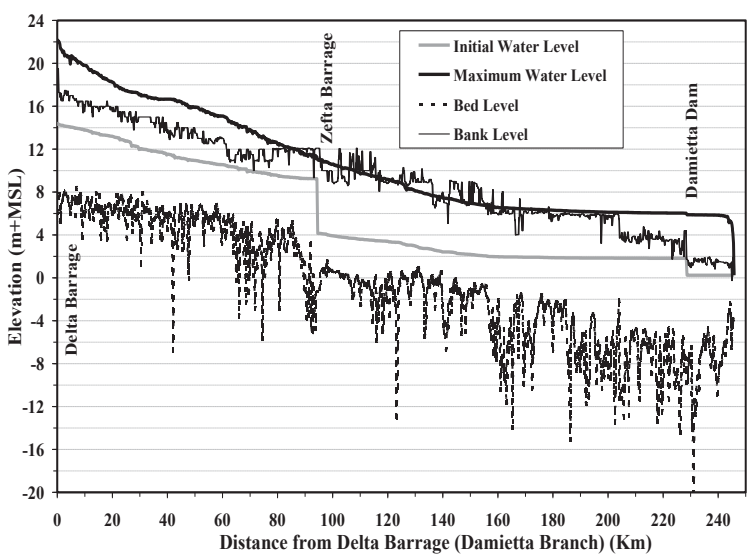

Figure (16): Peak water profile on Damietta Branch

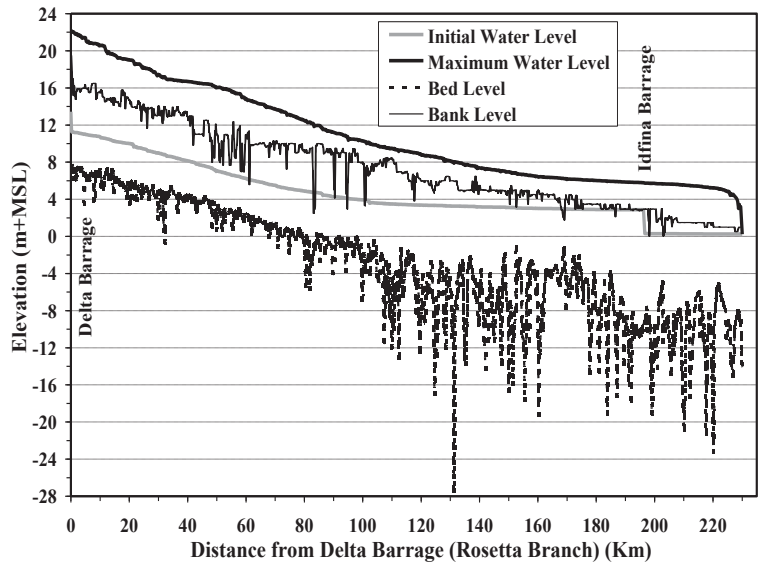

Figure (17): Peak water profile on Rosetta Branch 
NUMERICAL SIMULATION OF FLOOD INUNDATION OF DELTA LANDS IN CASE OF ASWAN HIGH DAM FAILURE

Helal, Sobeih, El-Belasy, El-gendy

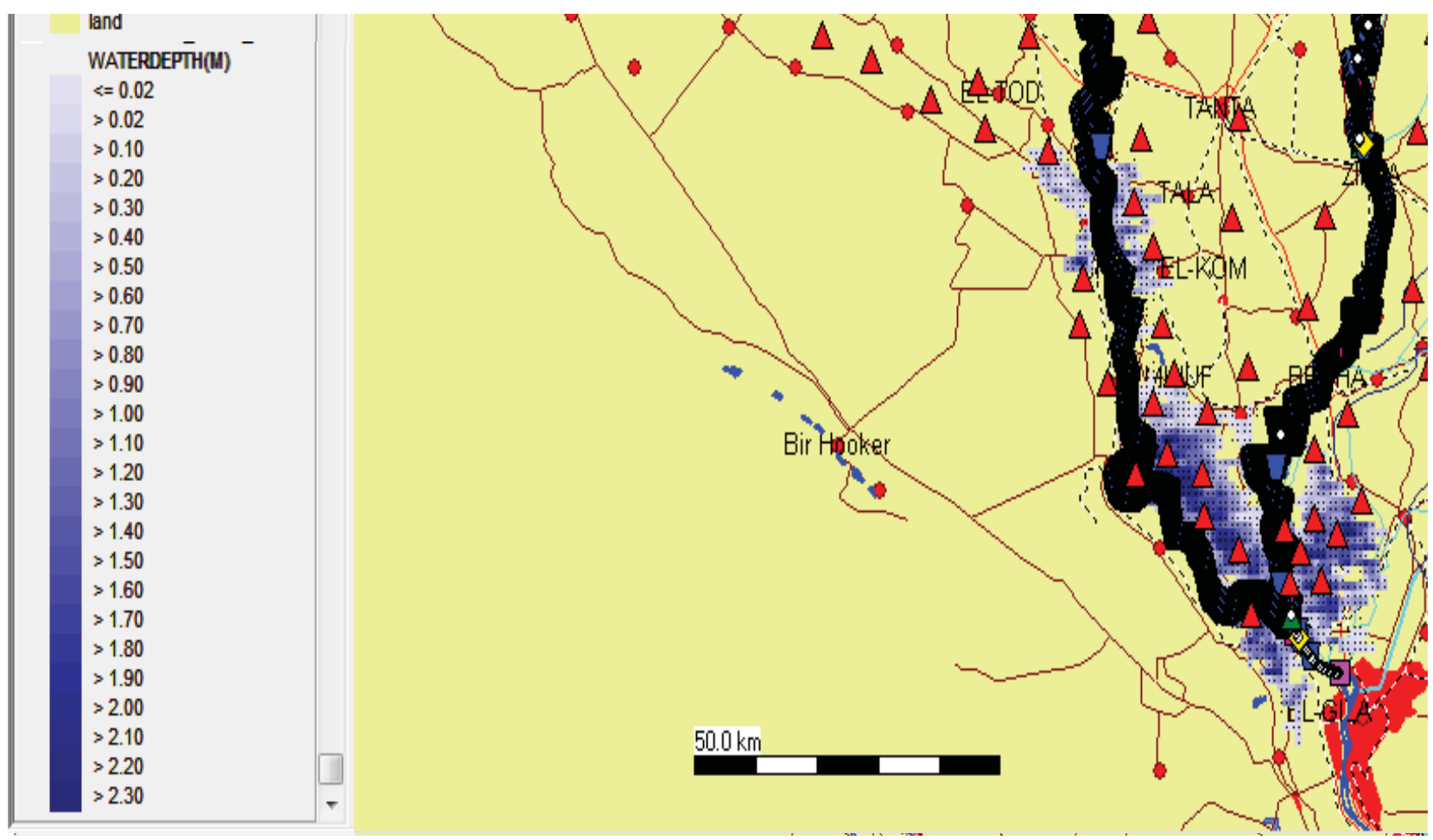

Figure (18): GIS map of inundated areas of Delta Lands after 1 week

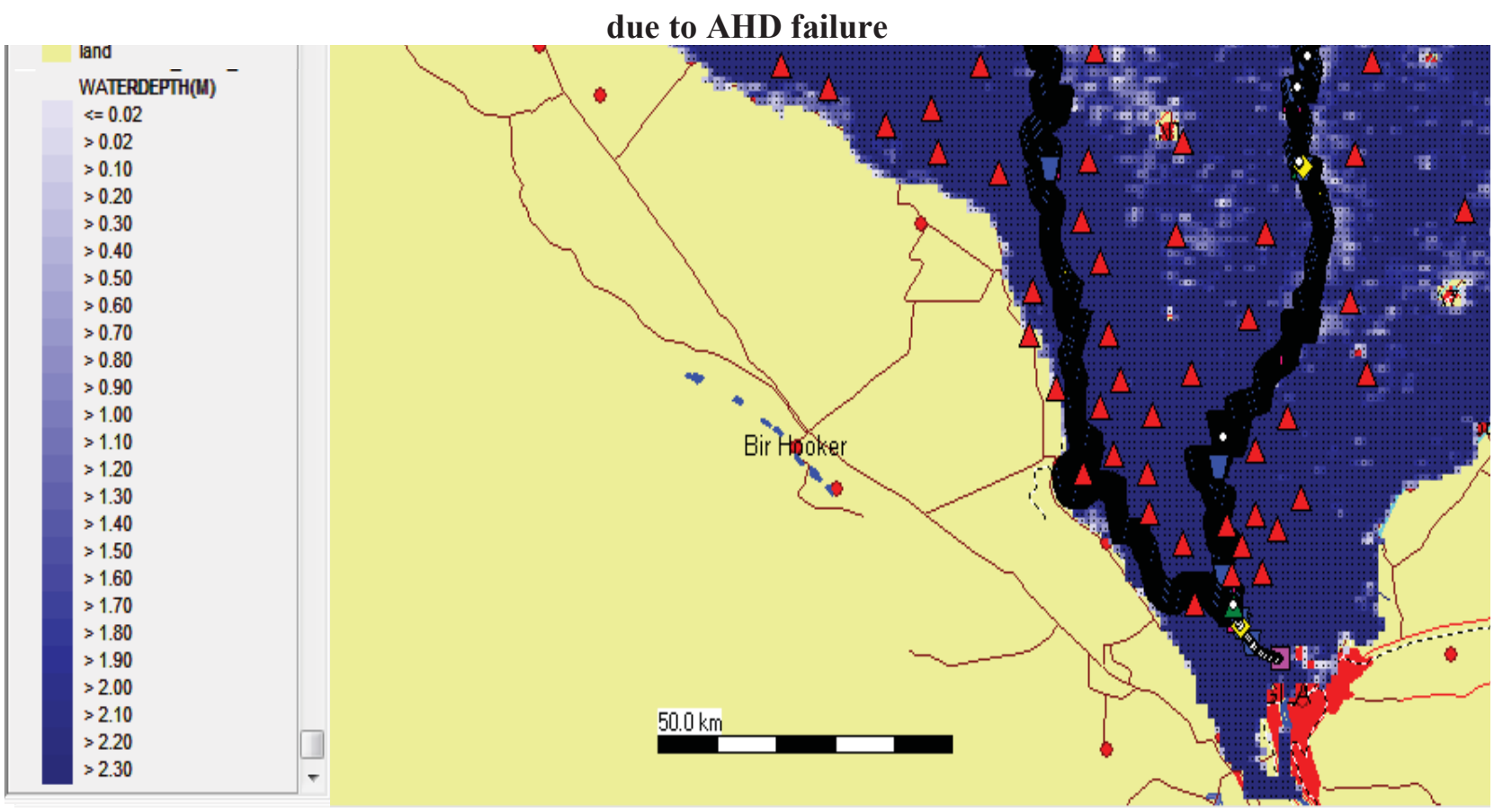

Figure (19): GIS map of inundated areas of Delta Lands after 4 months due to AHD failure 
NUMERICAL SIMULATION OF FLOOD INUNDATION OF DELTA LANDS IN CASE OF ASWAN HIGH DAM FAILURE

Helal, Sobeih, El-Belasy, El-gendy

Table (3): Inundation areas

\begin{tabular}{||l|c|c|c|}
\hline $\begin{array}{c}\text { Governorat } \\
\text { e }\end{array}$ & $\begin{array}{c}\text { Total } \\
\text { Area }\end{array}$ & $\begin{array}{c}\text { Inundated } \\
\text { Area } \\
\left(\mathrm{Km}^{2}\right)\end{array}$ & $\begin{array}{c}\text { Inundat } \\
\text { ed } \\
\text { percenta } \\
\text { ge } \\
\left(\mathrm{Km}^{2}\right)\end{array}$ \\
\hline \hline $\begin{array}{l}\text { EI } \\
\text { Menoufia }\end{array}$ & 2157.91 & 1559.33 & 72.26 \\
\hline EI Qalyubia & 1166.89 & 974.89 & 83.55 \\
\hline EI Gharbia & 1984.10 & 1830.80 & 92.27 \\
\hline Damietta & 860.30 & 712.19 & 82.78 \\
\hline EI Beheira & 11471.30 & 3972.15 & 34.63 \\
\hline Prot Said & 1339.12 & 1311.81 & 97.96 \\
\hline Alexandria & 2558.53 & 395.78 & 15.47 \\
\hline EI Sharqia & 4825.37 & 3332.70 & 69.07 \\
\hline EI Ismailia & 6196.34 & 794.84 & 12.83 \\
\hline EI Suez & 9439.33 & 76.49 & 0.81 \\
\hline EI Dakahlia & 3891.00 & 3404.05 & 87.49 \\
\hline Kafr & 3750.79 & 3468.15 & 92.46 \\
EI Sheikh & 49640.98 & 21833.18 & 43.98 \\
\hline Total & & & \\
\hline \hline
\end{tabular}

\section{CONCLUTIONS AND RECOMMENDATIONS}

\subsection{Conclusions}

The following was concluded:

1. Based on the results of simulations the following conclusions could be drawn:

a. Damietta Branch

The first propagating wave takes about $95 \mathrm{hr}$. to reach DS Delta Barrage and $119 \mathrm{hr}$ to reach US Damietta Dam, which allows a certain reaction time for evacuation plans.

- the maximum peak outflow of Delta Barrage
(Damietta Branch) is $5,515.64 \mathrm{~m}^{3} / \mathrm{s}$

- The wave travels downstream with a velocity ranges between 0.24 and $7.89 \mathrm{~m} / \mathrm{s}$.

- The water levels increase by $7.77-2.02 \mathrm{~m}$ in the first reach, $6.85-4.21 \mathrm{~m}$ in the second reach and $5.64 \mathrm{~m}$ in the third reach.

b. Rosetta Branch

- The first propagating wave takes about $116 \mathrm{hr}$ to reach US Idfina Barrage.

- The maximum peak outflow of Delta Barrage (Rosetta Branch) is $6960.86 \mathrm{~m}^{3} / \mathrm{s}$.

- The wave travels downstream with a velocity ranges between 0.30 and $6.59 \mathrm{~m} / \mathrm{s}$.

- The water levels increased by $8.81-2.91 \mathrm{~m}$ in the first reach, $5.44 \mathrm{~m}$ in the second reach.

2. The total gross flooded area resulted for this study is about $21833.18 \mathrm{~km}^{2}$.

\subsection{Recommendations}

The following considerations could be recommended for future studies:

- Each hydraulic structure on the Nile River should have its own emergency action plan tailored to the site specific condition, and an alarming system should be established along the main river system connecting all structures along the Nile and its two branches, computerized in a central unit similarly to Telemetry system.

- Preparing an emergency action plan with local authorities to organize evacuation plans in case of emergency.

- Study of the protection and raising of the Nile banks.

- Study of the need of increasing the capacity of Toshka Spillway.

- Planning of the future construction projects and new cities could be outside the boundary of inundation area. 


\section{NUMERICAL SIMULATION OF FLOOD INUNDATION OF DELTA LANDS IN CASE OF ASWAN HIGH DAM FAILURE}

Helal, Sobeih, El-Belasy, El-gendy

\section{REFERENCES}

[1] Delft Hydraulics (2009),"SOBEK manual.

Help", Technical Reference Manual. Delft Hydraulics, IHE, Delft, the Netherlands

[2] Dhondia J. F., and Stelling G. S "Application of One-Dimensional twoDimensional Integrated Hydraulic Model for Flood Simulation and Damage Assessment ", proceeding of the fifth international conference in hydroinformatic Cardiff, UK, Vol.1, pp. 265-276.

[3] El-Belasy A. (2008),"Inundation Modeling for the Nile Delta", Hydraulics Research Institute, NWRC, Egypt. Report No.181.

[4] Fahmy S, Helal E, El-Belasy A, Saad S, and Sobeih M. (2011), "Assessing the Risk of the Aswan High Dam Breaching", Engineering Research Journal, Faculty of Engineering, Menoufia University, Vol. No. 933.

[5] Fahmy S. Abdel Haleem, (2011), "Inundation Hazards and Flood Waves Propagation due to Dams Failures", Ph. D. Thesis, Civil Engineering Department, Faculty of Engineering, El- Menoufia University, Egypt.

[6] Hassan S. (2010), "Analysis of Hydraulic Hazards of Inundation of Delta Lands Due to Delta Barrages Failure", MSc. Thesis, Irrigation and Hydraulics Department, Cairo University, Egypt.

[7] Loucks D. P., and Beek E. V. (2005)," Water Resources Systems Planning and Management An Introduction to Methods, Models and Applications", Puplished by the UNESCO and WL I Delft Hydraulics, The Netherlands.

[8] Vanderkimpen P., Melger E., and Peeters P. (2009), " Flood Modeling for Risk Evaluation - a MIKE FLOOD vs. SOBEK1D2D benchmark study" Flood Risk Management: Research and Practice Samuels et al. (eds).

\section{NOTATION AND ABBREVIATIONS}

Notation

$$
\begin{aligned}
& A_{f} \quad \text { : conveying cross-section } \quad\left[\mathrm{L}^{2}\right] \\
& A_{t} \quad: \text { total cross-sectional area } \quad\left[\mathrm{L}^{2}\right] \\
& \text { C : Chézy coefficient [-] } \\
& g \quad \text { : gravitational acceleration } \quad\left[\mathrm{LT}^{-2}\right] \\
& \text { h : water level relative to [L] } \\
& \text { reference level } \\
& q_{L} \quad: \text { lateral inflow per unit } \quad\left[\mathrm{L}^{2} \mathrm{~T}^{-1}\right] \\
& \text { length } \\
& \text { Q : discharge } \quad\left[\mathrm{L}^{3} \mathrm{~T}^{-1}\right] \\
& R \quad \text { : hydraulic radius (roughly [L] } \\
& \text { equal to the water depth) } \\
& t \quad: \text { time } \quad[\mathrm{T}] \\
& W_{f} \quad \text { : width of conveying cross- [L] } \\
& \text { section at water surface } \\
& x \quad \text { : distance along the channel [L] } \\
& \alpha_{B} \quad \text { : Boussinesq coefficient } \quad \text { [-] }
\end{aligned}
$$
Abbreviations
AHD : Aswan High Dam,
AOD : Aswan Old Dam,
BCM : Billion Cubic Meters,
DEM : Digital Elevation Model,
GIS : Geographic Information System,
MCM : Million Cubic Meters,
MSL : Mean Sea Level, 